\title{
Isolation and Characterization of Klebsiella spp. and Staphylococcus aureus from Engorged Adult Females of Rhipicephalus spp.
}

\section{Ezdihar Mohammed Mahal Al-Rubaie ${ }^{1 *}$ (D), Nabeel M.H. Al-Maaly² ${ }^{(D)}$ and Haider Mohammed Ali Al-Rubaie ${ }^{3}$ (D)}

${ }^{1}$ Department of Microbiology, College of Veterinary Medicine, Baghdad University, Baghdad, Iraq. ${ }^{2}$ Department of Internal and Preventive Medicine, College of Veterinary Medicine, Baghdad University, Iraq. ${ }^{3}$ Department of Parasitology, College of Veterinary Medicine, Baghdad University, Baghdad, Iraq.

\begin{abstract}
To mention the role of ticks in transmission of Klebsiella spp. and Staphylococcus aureus, sixty seven engorged adult females of the type which called hard ticks (Rhipicephalus spp.) were collected from cattle and sheep randomly from diverse regions of Baghdad city through the period November 2015 till March 2016. Blood swabs from ticks were subjected to the culture media to determine the percentages of Klebsiella spp. and Staphylococcus aureus. Results showed that out of 67 samples, 13 (14.40\%) samples were positive for Klebsiella spp., 16 (23.88\%) samples were positive for Staphylococcus aureus and 8 samples were positive for both bacteria. This study revealed that hard ticks (Rhipicephalus spp.) is a good source for bacterial infection by Klebsiella spp. and Staphylococcus aureus .

Keywords: Rhipicephalus, Klebsiella, Staphylococcus.
\end{abstract}

*Correspondence: ezn_2009 @yahoo.com

(Received: 03 May 2019; accepted: 13 July 2019)

Citation: Ezdihar Mohammed Mahal Al-Rubaie, Nabeel M.H. Al-Maaly and Haider Mohammed Ali Al-Rubaie, Isolation and Characterization of Klebsiella spp. and Staphylococcus aureus from Engorged Adult Females of Rhipicephalus spp., J Pure Appl Microbiol., 2019; 13(3): 1763-1767. https://doi.org/10.22207/JPAM.13.3.51

(c) The Author(s) 2019. Open Access. This article is distributed under the terms of the Creative Commons Attribution 4.0 International License which permits unrestricted use, sharing, distribution, and reproduction in any medium, provided you give appropriate credit to the original author(s) and the source, provide a link to the Creative Commons license, and indicate if changes were made. 


\section{INTRODUCTION}

Arthropods considered as a vectors of numerous pathogens which cause an important diseases in animal and human (Hill et al., 2005) and especially hard ticks which are ecto-parasites sucking the blood and may be present in all regions in the world. Ticks are a vectors of the large range of causative microorganisms (viruses, bacteria, rickettsia and parasites) and they spread a greater variety of infectious microorganisms than any other arthropods (Andreotti et al., 2011). When this arthropod is endemic, it was hinders the livestock production in many tropical in addition to subtropical regions (Grisiet al., 2002).

Ticks are amongst the mainly transmitted vectors of veterinary and medical importance pathogens (de la Fuente et al., 2008).

There are most favorable environmental conditions and biotopes for each tick species, and these establish the geographic distribution of the ticks and determine the risk areas for tick-borne diseases, mainly when ticks are both vectors and reservoirs of pathogens (Parola and Raoult, 2001). The infectious diseases which transmitted by the ticks are extremely increased and some bacterial diseases which transmitted by this arthropod considered as globally threatening (Hotez and Kamath, 2009; Heymanet al., 2010). Many studies pointed to the isolation of pathogenic bacteria from the ticks which picked from sheep and cattle (Murrell et al., 2003; Barandika et al., 2008). Murrell et al. (2003) referred that many common bacteria were isolated from arthropods such as lice, fleas, and ticks, these bacteria include Stenotrophomonas, Staphylococcus, Pseudomonas, Acinetobacter and Bacillus. Because of tick's biological nature and its habits in sucking the blood (hematophagous) that lead to increase the variety of microorganisms in this arthropod (Heiseet al., 2010).

The role of the tick on extend of humans and animals infectious diseases is still limited, but has recently received an attention, for that reason, this study was delineate for bacterial isolation (Klebsiella spp and Staph aureus) from engorged mature females of Rhipicephalus spp.

\section{MATERIALS AND METHODS}

Sixty seven adult female of hard ticks of the spp Rhipicephalus were collected from domesticated cattle and sheep in Baghdad city through period starting from November /2015 till March /2016. To uncontaminated the ticks, they were dipped in ethyl alcohol $70 \%$ and then leave 5 minutes to dry. Then the ticks was punctured by a cut for blood swabs and subjected to culture on the blood agar for primary isolation. The blood agars were incubated for $24 \mathrm{hrs}$ at $37^{\circ} \mathrm{C}$. After $24 \mathrm{hrs}$ all growth colonies would be subjected to subculture on specific media (MacConkey agar and mannitol salt agar) for $24 \mathrm{hrs}$ at $37^{\circ} \mathrm{C}$ to isolate Klebsiella $\mathrm{sp}$. and Staph aureus. After the appearance of growth on these specific media gram stain was done to determine the gram stain, shape, size and arrangement of these bacteria. Capsule stain was made to the pink mucoid colonies that grew on MacConkey media. For identification of the Klebsiella, specific biochemical tests for this bacteria were done which include IMViC tests (indole, methyl red, voges-proskauer and simmons citrate) and then bio-chemical tests were done for yellowish golden colonies which grow on Mannitol salt agar which include coagulase test in addition to catalase test was done (Quinn et al., 2004).

\section{Statistical Analysis}

The final data were analyzed by use system SAS (2012), and Chi-square test was utilized to evaluate the significant differences at level $\mathrm{P} \leq$ 0.05 .

\section{RESULTS}

Results of this study showed that Klebsiella sp. and Staph aureus bacteria were isolated from engorged mature females of Rhipicephalus spp. hard ticks. Klebsiella spp. was

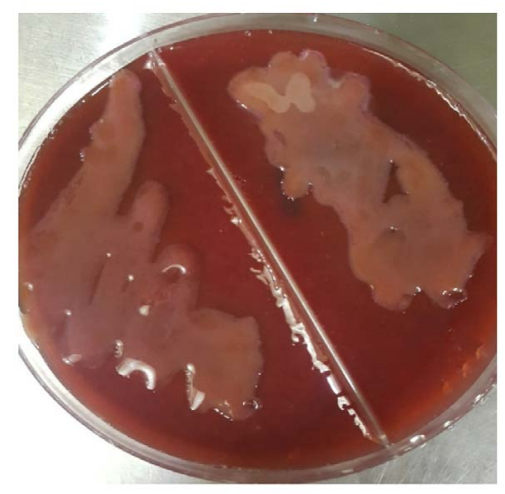

Fig. 1. Pale pink mucoid colonies of Klebsiella on MacConkey agar. 
isolated from 13 samples of 67 tick samples in an infection rate $14.40 \%$, while Staph aureus was isolated from 16 samples of 67 tick samples in an infection rate $23.88 \%$ and both bacteria were isolated from the same tick sample in an infection rate $11.94 \%$ (8/67).

Klebsiella sp. growth on MacConkey agar was showed pale pink mucoid colonies (Fig. 1), it was positive for capsular stain (Fig. 2) and the result of biochemical tests for Klebsiella spp showed that indole and methyl red were negative while voges-proskauer and simmons citrate were positive.

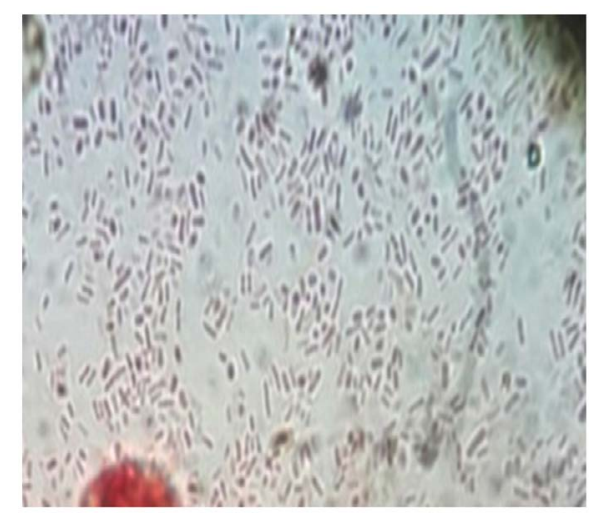

Fig. 2. Klebsiella stained with capsular stain.

Also Staphylococcus aureus were isolated on blood agar and sub-cultured on mannitol salt agar which showed yellowish golden colonies (Fig. 3). These colonies showed positive result for catalase and coagulase tests which are specific results for Staphylococcus aureus (Quinn et al., 2004).

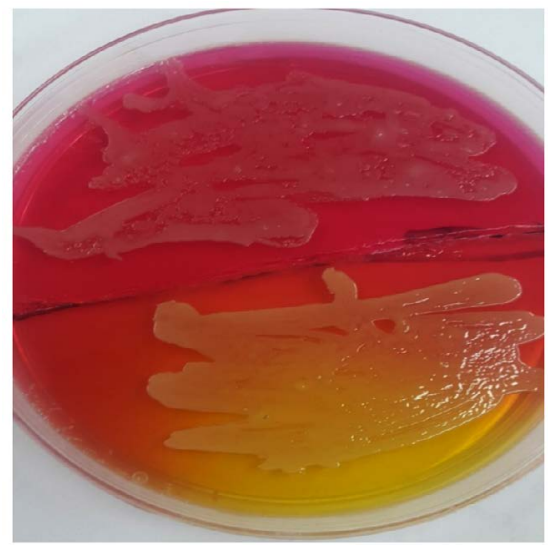

Fig. 3. Yellowish golden colonies of Staphylococcus aureus on Mannitol salt agar.

\section{DISCUSSION}

The biochemical tests which achieved in this study were including; IMViC to diagnose the pink mucoid colonies on MacConkey which suspected to be Klebsiella and after achieving the test it showed indole negative because it doesn't have tryptophanase enzyme that showed colorless ring after adding the Kovac's reagent and the colonies gave negative for methyl red test as its showed yellow color but in voges-Proskauer test its showed positive result after adding the reagents and red colour appeared, in addition to positive result for simmons citrate as the media became blue in color that interprets the usage of citrate and change the media to alkaline $\mathrm{pH}$; for suspected colonies of Staphylococcus aureus which grew on Mannitol salt agar with yellowish golden color, coagulase and catalase test were achieved, in catalase test they gave babbles that mean this colony was positive for this test. In coagulase test it gave positive result as clumping was appear on the slide.

Arthropods convey diverse of infectious agents and held a varied group of local microorganisms include bacteria and fungi (Abraham et al., 2017). Ticks regard as the mainly related vectors of pathogens causing disease in the wild and domestic animals and the cattle tick, Rhipicephalus (Boophilus) microplus, where it is endemic, hinder animals production in both subtropical and tropical parts of the world (Andreotti et al., 2011), and the significance of ticks in its ability to spread pathogenic microorganisms (Goddard, 2008) such as Borrelia, Ehrlichia, Francisella Rickettsia, Anaplasma and Babesia (de la Fuente et al., 2008), but only a very few reports the isolation of bacteria from hard ticks that infested animals (Rahman and Rahman, 1980; Amoo et al., 1987; Parola and Raoult, 2001; Vilcinset al., 2009; Heise et al., 2010; Andreotti et al., 2011 and Lalzar et al., 2012).

The results of the study differed from Rahman and Rahman (1980) who conducted a study in Bangladesh by homogenating Rhipicephalus microplus and isolated Enterobacter, Pseudomonas, and Staphylococcus, . Amoo et al. (1987) used the hemolymph to isolate Staphylococcus aureus from adult females and their eggs. Abraham et al. (2017) observed eight genera including Staphylococcus, Corynebacterium, Acinetobacter, 
Enterococcus, Lysinibacillus, Pseudomonas, and Rickettsia in Ixodesscapularis nymphs. Andreotti et al. ( 2011) identified bacteria at the spp. level include Staphylococcus aureus, Streptococcus dysgalactiae, Staphylococcus chromogenes, Staphylococcus sciuri, Corynebacterium glutamicum, Serratia marcescens and Finegoldia magna. Staphylococcus aureus observed in adult males and also in gut and eggs of adult female in cattle ticks and Stap aureus are the main genera of the bacterial community in the tick samples. Staph were less than $18 \%$ in adult males and eggs, but not in adult female ticks; Klebsiella $1.3 \%$ in adult female ticks, that may be due to the environmental contamination, seasons, and type of food used for feeding the animals lead to make a diversity in distribution of livestock having bacteria (Shahzadet al., 2013) or due to the environmental factors that ticks have manners which facilitates the touch with microorganisms in the surroundings that expands the difficulty of bacterial communities to reside on a tick's exoskeleton and a definitive mechanism which enables the tick to act as a vector which aid the spread of microbes across the hosts and probably influence environmental aspects (Andreotti et al., 2011).

Also, the form of bacterial types influenced by the environment, where the eggs are deposited (Hendry and Rechav, 1981). Within vectors, microbial communities have an significant roles in the capability of pathogens to persist and colonize and transmitted to their host (Cirimotich et al., 2011 and Weiss and Aksoy, 2011). On the same hand, Lalzar et al. (2012) stated that Rickettsia were found in $26 \%$ of the tested ticks and this comprised fewer than $10 \%$ of the bacterial isolation in females and up to $50 \%$ in males, but the density of Rickettsia was considerably lesser than that of Coxiella spp. that sustain association facultative between the tick and Rickettsia and the dynamics and interface patterns may govern of diverse bacterial physiological characteristics. In addition, intrinsic and extrinsic factors may be sharing the environment variation affect the bacterial communities' composition of arthropod.

Also, the microbiota of arthropods acts an significant role in pathogen resistance, development, physiology of the host, and nutrition (Belongia, 2002) and some factors clarify the low occurrence or plenty of primary or secondary endo-symbionts such as competition, and increased virulence during vertical transmission (Mira and Moran, 2002). Our conclusion, ticks are a good source of Klebsiella spp. and Staphylococcus aureus with easily isolated pathogenic bacteria in the field and may be have a main role in the transmission of these bacteria to the domestic animals.

\section{ACKNOWLEDGEMENTS}

None.

\section{CONFLICTS OF INTEREST}

The authors declare that there is no conflict of interest.

\section{AUTHORS' CONTRIBUTION}

All authors listed have made a substantial, direct and intellectual contribution to the work, and approved it for publication.

\section{FUNDING}

None.

\section{DATA AVAILABILITY}

All datasets generated or analyzed during this study are included in the manuscript.

\section{ETHICS STATEMENT}

This article does not contain any studies with human participants or animals performed by any of the authors.

\section{REFERENCES}

1. Abraham N.M., Liu L., Jutras B.L., Yadav A.K., Narasimhan S., Gopalakrishnan V., Ansari J.M., Jefferson K.K., Cava F., Jacobs-Wagner Ch. And Fikrig E. Pathogenmediated manipulation of arthropod microbiota to promote infection. PNAS., 2017; 12: E781-E790. https://doi.org/10.1073/pnas.1613422114.

2. Amoo A.O., Dipeolu O.O., Akinboade A.O. and Adeyemi A. Bacterial isolation from and transmission by Boophilusdecoloratus and Boophilusgeigyi. Folia. Parasitol., 1987; 34: 69-74.

3. Andreotti R., Pırez de Leףn A.A., Dowd S.E., Guerrero F.D., Kylie G., Bendele K.G. and Scoles G.A. Assessment of bacterial diversity in the cattle tick Rhipicephalus (Boophilus) microplus through tag-encoded pyro sequencing. B.M.C. Microbiol., 2011; 11: 6. https://doi.org/10.1186/1471-2180-11-6.

4. Barandika J.F., Hurtado A., GarcDa-Sanmarton J., Juste R.A., Anda P., and GarcDa-P'rez A.L. Prevalence of TickBorne Zoonotic Bacteria in Questing Adult Ticks from Northern Spain. vector-borne and zoonotic diseases, 
Mary Ann Liebert, Inc. 2008; 8(6): DOI: 10.1089/vbz. https://doi.org/10.1089/vbz.2008.0023.

5. Belongia E.A. Epidemiology and impact of coinfections acquired from Ixodesticks. Vector Borne Zoo. Dis., 2002; 2(4): 265-273. https://doi. org/10.1089/153036602321653851.

6. Cirimotich C.M., Ramirez J.L. and Dimopoulos G. Native microbiota shape insect vector competence for human pathogens. Cell Host Microbe, 2011; 10(4):307-310. https://doi.org/10.1016/j.chom.2011.09.006.

7. de la Fuente J., Estrada-Pena A., Venzal J.M., Kocan K.M. and Sonenshine D.E. Overview:Ticks as vectors of pathogens that cause disease in humans and animals. Fronts Biosci., 2008; 13: 6938-6946.

8. Goddard J. Infectious Diseases and Arthropods. $2^{\text {nd }}$ ed. Humana Press, 2008; 81-123. https://doi. org/10.1007/978-1-60327-400-5_4.

9. Grisi L., Massard C.L., Moya-Borja G.E. and Pereira J.B. Impacto econgmico das principais ectoparasitoses em bovinos no Brasil. A HoraVeterinבria., 2002; 21: 8-10.

10. Heyman P., Cochez C., Hofhuis A., van der Giessen J., Sprong H., Porter S.R., Losson B., Saegerman C., Donoso-Mantke O., Niedrig M. and Papa A. A clear and present danger: tick-borne diseases in Europe. Expert. Rev. Anti. Infect. Ther., 2010; 8: 33-50. https://doi.org/10.1586/eri.09.118.

11. Heise S.R., Elshahed M.S. and Little S.E. Bacterial diversity in Amblyomma americanum (Acari: (xodidae) with a focus on members of the genus Rickettsia. J .Med. Entomol., 2010; 47: 258-268. https://doi.org/10.1093/jmedent/47.2.258.

12. Hendry D.A. and Rechav Y. Acaricidal bacterial infecting laboratory colonies of the tick Boophilus decoloratus (Acarina: Ixodidae). J. Inv. Pathol., 1981; 38: 149-151. https://doi.org/10.1016/0022-2011(81)90044-6.

13. Hotez P.J. and Kamath A. Neglected tropical diseases in sub-Saharan Africa: review of their prevalence, distribution, and disease burden. PloS Negl. Trop. Dis., 2009; 3: e412. https://doi.org/10.1371/journal.pntd.0000412.

14. Hill C.A., Kafatos F.C., Stansfield S.K. and Collins F.H. Arthropod-borne diseases:Vector control in the genomics era. Nat. Rev.Microbiol., 2005; 3(3): 262-268. https://doi.org/10.1038/nrmicro1101.

15. Lalzar I., Harrus Sh., Mumcuoglu K.Y. and Gottlieba Y. Composition and seasonal variation of Rhipicephalus turanicus and Rhipicephalus sanguineus bacterial communities. Appl. Env. Microbiol., 2012; 78(12): 4110-4116. https://doi.org/10.1128/AEM.00323-12.

16. Mira A. and Moran N.A. Estimating population size and transmission bottle necks in maternally transmitted endosymbiotic bacteria. Microb. Ecol., 2002; 44: 137-143. https://doi.org/10.1007/s00248-002-00129.

17. Murrell A., Dobson S.J., Yang X., Lacey E. and Barker S.C. A survey of bacterial diversity in ticks, lice and fleas from Australia.Parasitol. Res., 2003; 89: 326-334.

18. Parola P. and Raoult D. Ticks and tick-borne bacterial diseases in humans: an emerging infectious threat. Clin. Inf. Dis., 2001; 32: 897-928. https://doi.org/10.1086/319347.

19. Quinn P.J., Carter M.E., Markey B. and Carter G.R. Clinical Veterinary Microbiology. $6^{\text {th }}$ ed. Mosby ANIMP Wolf, London, 2004; $13-17$.

20. Rahman M.H. and Rahman M.M. Occurrence of some bacterial isolates in ticks found in Madhupur forest area. Bang. Vet. J., 1980; 14: 43-47.

21. SAS. Statistical Analysis System, User's Guide. Statistical. Version $9.1^{\text {th }}$ ed. SAS. Inst. Inc. Cary. N.C. USA, 2012.

22. Shahzad K.A., Muhammad K., Sheikh A.A., Yaqub T., Rabbani M., Hussain T., Anjum A.A. and Anees M. Isolation and molecular characterization of Shiga toxin producing E. coli O 157. J. Anim. Plant Sci., 2013; 23(6): 1618-1621.

23. Vilcins I.E., Fournier P., Old J.M. and Deane E. Evidence for the presence of Francisellaand spotted fever group Rickettsia DNA in the tick Amblyomma fimbriatum (Acari: Ixodidae), Northern territory, Australia. J. Med. Entomol., 2009; 46: 926-933. https://doi.org/10.1603/033.046.0427.

24. Weiss B. and Aksoy S. Microbiome influences on insect host vector competence. Trends Parasitol., 2011; 27(11): 514-522. https://doi.org/10.1016/j. pt.2011.05.001. 